\title{
Aikuiskasvatus, sosiologia ja arkielämä
}

\author{
TAPIOAITTOLA
}

\section{Aikuiskasvatustiede ja arkielämä}

Aikuiskasvatus ja arkielämä ovat monilla merkityksillä täytettyjä käsitteitä ja niiden tutkimuksella on omat tutkimustraditionsa. Arkielämä on meille kaikille tuttu, mutta viime vuosien tutkijapuheenvuoroissa on huolestuneina todettu, että tavallinen arki olisi katoamassa. Arkielämä on ollut jotain itsestään selvää, tuttua ja turvallista, mutta nyt sekin on muuttumassa samalla tapaa epävakaaksi ja vaikeasti ennakoitavaksi kuin nykyinen työelämä. Zygmunt Baumanin (2007, 1-4) mielestä nykyisessä "notkean modernin” vaiheessa ihmisten yksilölliset pyrkimykset ja elämänsuunnitelmat kohtaavat ennennäkemättömiä haasteita, eivätkä sosiaaliset instituutiot, kulttuuriset traditiot tai perinteiset identiteettimallit enää tarjoa riittävästi tukea ihmisten elämälle, valinnoille ja tulevaisuudensuunnitelmille. Elämästä on tulossa päättymätön sarja erilaisia lyhytkestoisia episodeja ja projekteja, joiden kuvaamiseen ei voida soveltaa "uran” tai "kehityksen” kaltaisia käsitteitä. Tarkastelen seuraavassa, miten aikuiskasvatustiede ja aikuiskoulutus sekä ihmisten arkielämä liittyvät toisiinsa ja miten aikuiskasvatuksen sosiologia lähestyy näitä kysymyksiä.

Arkielämästä on viime vuosina tullut keskeinen tutkimuskohde yhteiskuntatieteissä, naistutkimuksessa ja kulttuurintutkimuksessa, mutta ei vielä kasvatustieteessä tai aikuiskasvatustieteessä. Arkielämään kohdistuva tutkimus on ollut Henri Lefebvre'n vuonna 1947 julkaiseman "Critique of Everyday Life” (2008) teoksen ilmestymisen jälkeen eriytyneenä erilaisiin tutkimussuuntauksiin, jotka eivät ole keskustelleet toistensa kanssa. Arkielämän tutkimustraditiossa korostetaan Agnes Hellerin (1984) tavoin, että arki on yhdessä jaettua reflektoimatonta kokemusta päivän rutiineista ja arkisista käytännön toimista. Naistutkimus on Rita Felskin (2000) mukaan kiinnostunut arjen paradokseista sekä arjen ”arkisuutta” organisoivis- ta aikaa, tilaa ja modaalisuutta koskevista jäsennyksistä sekä niihin kätkeytyvistä sukupuolispesifeistä rakenteista ja käytänteistä. Arkipäivän fenomenologinen tutkimustraditio puolestaan tutkii arkea, Alfred Schutzin ja Thomas Luckmannin (1973) esimerkin ohjaamana ihmisten jokapäiväisen elämismaailman perusrakenteiden sekä niiden mahdollistamien toimintojen ja merkitysten muodostamana kokonaisuutena. Elämismaailma on kaiken inhimillisen toiminnan perusta ja tapahtumatila ja siihen sisältyvät kaikki elämän kannalta tärkeät elementit, kuten toiset ihmiset, yhteiskunta eri instituutioineen, luonto ja kulttuuri.

Nykyisessä arjen ja arkielämän tutkimuksessa nämä tutkimussuuntaukset ovat kuitenkin lähentyneet toisiaan ja viime vuosina arkielämää on tutkittu etenkin kulttuurisen modernisoitumisen näkökulmasta, minkä ohella käsitys arjesta on laajentunut koskemaan ihmisten tärkeät elämänalueet (ks. Bennett 2005; Chaney 2002, Highmore 2002). Arkielämä on ollut jotain itsestään selvää, tuttua ja turvallista "kodintuntua”, mutta joka kuitenkin on alituiseen vaarassa hävitä tai muuttua joksikin muuksi. Samoin havainnot siitä, että työn ja arkielämän väliset suhteet ovat alkaneet hämärtyä, ovat asettaneet arjen uudella tapaa merkitykselliseksi tutkimuskohteeksi (Jokinen 2005).

Aikuiskasvatustieteellä on pitkä historia kansalaiskasvatuksen ja vapaan sivistystyön kehittäjänä ja ylläpitäjänä. Aikuiskasvatuksen tutkimuksellinen painopiste on kuitenkin viime aikoina muuttunut siten, että suuri osa nykyistä tutkimusta käsittelee aikuiskoulutuksen tai työelämän kysymyksiä, kun taas vapaan sivistystyön järjestösuuntautunut tutkimusperinne on jäänyt vähemmälle huomiolle (ks. Suoranta \& Salo 2002). Arkipäivään kohdistuva tutkimus on myös ollut vähäistä, vaikka nykyiset työelämän muutoksiin, aikuiskoulutuksen relevanssiin, informaaliseen oppimiseen, aikuisten elämänhistorioihin ja aktiiviseen kansalaisuuteen liittyvät kysymykset ovat 
tehneet arkielämästä myös aikuiskasvatuksen kannalta tärkeän tutkimuskohteen (ks. Alheit \& Bausien 2000; Johston 2005, Schuller \& Preston 2005).

Suomalaisessa aikuiskasvatuksessa arkielämää on lähestytty lähinnä oppimisen näkökulmasta (Sallila \& Vaherva 1998), minkä ohella arkea on sivuttu aikuisten elämänhistorioihin, koulutuskokemuksiin ja aktiiviseen kansalaisuuteen kohdistuneissa tutkimuksissa (Antikainen, Houtsonen, Kauppila \& Huotelin 1996; Laitinen \& Nurmi 2003). Viimeaikaisissa tutkimuksissa on käynyt myös ilmi, että monet aikuiskoulutukseen osallistumattomuuden syyt löytyvät juuri ihmisten arkielämän jännitteistä (Antikainen 2005; Moore, 2004). Aikuiskasvatuksen sosiologian tutkimuskohteeksi voisivat siten aikuiskoulutuksen ja työelämän ohella tematisoitua muutkin arkielämään sisältyvät elämänalueet kuten, sosiaaliset verkostot, perhe ja kulttuuri sekä erilaiset vapaa-ajan toiminnot, kuten joukkotiedotus, kuluttaminen ja uusi teknologia sekä näiden elämänalueiden yhteydet aikuisten oppimiseen ja identiteetin rakentumiseen.

\section{Aikuiskasvatuksen sosiologia ja aikalaisdiagnoosit}

Arkielämään samoin kuin aikuiskoulutukseen ja työorganisaatioihin kohdistuva tutkimus hyödyntää mielellään sosiologista käsitteistöä ja teoreettisia ajatusrakennelmia. Lainattaessa sosiologisia käsitteitä ja teoreettisia ideoita keskeiseksi pohdinnan aiheeksi nousee niiden siirrettävyys ja anti aikuiskasvatustieteelliselle tutkimukselle (Antikainen 1998). Tämä kysymys on ajankohtainen sen vuoksi, että keskeisimmät (kasvatus)sosiologian teoreetikot Basil Bernstein, Pierre Bourdieu, Paul Willis ja Thomas Ziehe kuvanneet teollista yhteiskuntavaihetta ja sen koulutusjärjestelmään liittyviä tekijöitä (Aittola toim. 1999). Vasta viimeaikaiset sosiologiset aikalaisdiagnoosit ja kriittisen pedagogiikan edustajat, kuten Henry Giroux keskittyvät myöhäismodernin yhteiskunnan erityispiirteiden ja sen pedagogisten seurausten analysointiin.

Sosiologista aikalaisdiagnooseista onkin tullut tärkeä osa aikuiskasvatuksen parissa tehtävien tutkimusten viitekehystä ja tutkijat ovat saaneet niistä ideoita, käsitteitä ja näkökulmia omiin tutkimuksiinsa. Aikalaisdiagnoosin käsitteen käyttö on yleistynyt vasta viime vuosina vaikka sen juuret ovat kaukana sosiologian historiassa Karl Mannheimin analyyseissa (Mannheim 1947; Noro 2007).
Aikalaisdiagnoosit kuvaavat kriittisesti oman aikakautemme yhteiskunnan muutoksia, kuten Ulrich Beckin riskiyhteiskuntaa, Anthony Giddensin jälkitraditionaalista yhteiskuntaa, Manuel Castellsin verkostoyhteiskuntaa tai Richard Sennettin uuden kapitalismin kulttuuria koskevat analyysit osoittavat. Näissä kaikissa luodaan jokin keskeisen ilmiön ympärille rakentuva ideaalityyppinen kuvaus modernisaation vaikutuksista yhteiskunnan eri osa-alueilla - taloudessa, kulttuurissa ja identiteetin rakentumisessa.

Aikalaisdiagnooseille tyypillistä sosiologista ajattelutapaa voidaan havain-

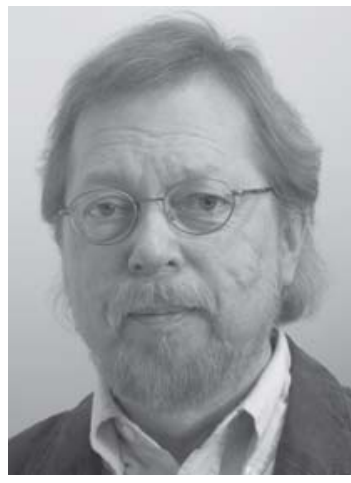

Tapio Aittola nollistaa seuraamalla Richard Sennettin (2007, 113) kuvausta työelämän instituutioiden, kulttuurin ja identiteettimuodostuksen välisistä suhteista. Seuraavat lainaukset on poimittu teoksensa "Uuden kapitalismin kulttuuri” - teoksen johdantoluvusta.

"Suurten instituutioiden pirstaloituminen on rikkonut myös monien ihmisten elämän: työpaikat muistuttavat enemmän rautatieasemia kuin kyläyhteisöjä, ja perheet kadottavat suuntansa. Liikkuvuus on globaalin aikakauden ikoni, on mentävä eteenpäin pikemmin kuin asetuttava aloilleen. Instituutioiden poistaminen ei ole lisännyt yhteisöllisyyttä. (...) Tässä kohden kuvaan astuu kulttuuri. (...) Millaiset arvot ja toimintatavat voivat sitoa yhteen ihmisiä, kun instituutiot heidän ympärillään murenevat? Minun sukupolveni vastaus, pienten yhteisöjen ylistäminen, oli varsin mielikuvitukseton. Yhteisöllisyys ei ole ainoa liima, joka pitää kulttuuria koossa. (...) Vain tietyntyyppiset ihmiset menestyvät epävakaissa, pirstaloituneissa yhteiskunnallisissa olosuhteissa. (...) Yksilö, jonka aikajänne on lyhyt, joka keskittyy potentiaalisiin kykyihinsä ja joka on valmis hylkäämään aiemmat kokemukset, on - kauniisti sanottuna - erityislaatuinen ihminen. Useimmat eivät ole sellaisia: he tarvitsevat jatkuvuutta elämäänsä, ovat ylpeitä siitä että ovat hyviä jossain tietyssä asiassa, arvostavat elämänkokemuksiaan. Uusien instituutioiden edellyttämä kulttuurinen ihanne on sen vuoksi monille ihmisille vaurioittava." 
Sennett tuo heti teoksensa alussa esiin työnsä peruskoordinaatit sekä esittää näkemyksensä siitä, miten työelämän instituutioiden hajoaminen heijastuu kulttuuriin ja arvoihin sekä rapauttaa pienyhteisöjen toimintaa, minkä ohella hän pohtii näiden muutosten kielteisiä seurauksia ihmisten elämälle, ammattitaidolle ja identiteetille. Aikalaisdiagnoosit ilmentävät hyvin C. Wright Millsin (1978, 215-248) "sosiologista mielikuvitusta", jonka avulla analysoidaan yhteiskunnan eri osien välistä yhteen kietoutumista. Aikalaisdiagnooseissa kuvataan teollisen yhteiskuntavaiheen instituutioiden ja tuotannollisten perusrakenteiden murtumista ja uusien joustavien rakenteiden ja instituutioiden esiintuloa sekä niiden seurauksia. Tämän lisäksi aikalaisdiagnooseissa kuvataan kulttuuristen ja sosiaalisten traditioiden murtumista tai muuttumista neuvoteltaviksi sekä analysoidaan yksilöllistymisen seurauksia ihmisten elämälle.

Sosiologisten aikalaisdiagnoosien anti aikuiskasvatuksen tutkimukselle on se, että vaikka tarkasteltavat ilmiöt vaihtuisivat toisiin, niin niiden avulla on luotu toimiva teoreettinen malli ja käsitteellinen viitekehys yhteiskunnan ja samalla myös arkielämän eri osa-alueiden yhteen kietoutumisen tarkastelulle. Jürgen Wittpoth (2001, 155-176) onkin todennut, että aikalaisdiagnoosit kiinnittävät huomiota keskeisiin taloudellisiin, kulttuurisiin, sosiaalisiin ja yksilötason muutoksiin, jotka säätelevät aikuiskoulutuksen ja aikuiskasvatuksen toimintaympäristöä. Aikuiskasvatukselle ja etenkin aikuiskasvatuksen sosiologialle aikalaisdiagnoosit antavat hyvän perustan tutkia ja analysoida yhteiskuntaan, aikuiskoulutukseen, työelämään, vapaaseen sivistystyöhön, aktiiviseen kansalaisuuteen ja identiteetin rakentumiseen liittyviä ilmiöitä.

\section{Aikuiskoulutus ja arkielämä}

Myöhäismoderni maailma on täynnä erilaisia valinnan mahdollisuuksia, jotka ovat samalla myös pakkoja. Ihmiset tietävät, että "modernin projektin” päättyminen on johtanut heidät erilaisia riskejä ja uhkia täynnä olevaan maailmaan, jossa eläminen edellyttää jatkuvaa valintojen tekemistä, joustavuutta ja uusien asioiden omaksumista. Ihmisten elävät yhä epävakaammassa maailmassa, jossa Ulrich Beckin (2002, 22-29) mukaan erilaiset yhteiskunnalliset ja lähiympäristöön liittyvät turvaverkot ovat häviämässä ja yksilöt joutuvat elämään olosuhteissa, joita määräävät erilaisten ins- tituutioiden luomat ennakoimattomat epävarmuudet ja riskit sekä yksilöllistynyt pärjäämisen pakko. Aikuiskoulutukselle ihmisten arkielämän ja yhteiskunnallisten instituutioiden epävakaus merkitsee tarvetta luopua perinteisestä instituutiokeskeisestä koulutusajattelusta ja yritystä integroida aikuisten opetus ja oppiminen sellaisiin työ- ja arkielämän kannalta relevantteihin tietoihin, taitoihin ja toimintakompetensseihin, joita ihmiset tarvitsevat oman elämänsä ja ammattitaitonsa tueksi.

Aikuiskoulutuksen ongelmana on ollut koulutuksen kasautuvuus ja toisaalta heikko kattavuus aikuisten keskuudessa. Suomessa suurelta joukolta aikuisista puuttuu edelleen ammatillinen tutkinto. Sama osallistumisen kasautumisongelma on havaittavissa vapaan sivistystyön ja kansalaisjärjestöjen toiminnassa, vaikka ne voivatkin aikuiskoulutusta joustavammin tavoittaa eri kansalaispiirit. Nämä aikuiskoulutuksen ja vapaan sivistystyön ongelmat nivoutuvat myös erilaisiin näkemyksiin kansalaisuudesta. Rennie Johnstonin (2005, 4763) mukaan nykyisiä kansalaisuuskäsityksiä erottelee näkemys siitä, pidetäänkö kansalaisuutta perinteiseen tapaan statuksena ja saavutettuna etuna vai jatkuvaa oppimista ja yksilöiden omaa aktiivisuutta edellyttävänä toimintana. Tämä peruserottelu johtaa myös erilaisiin käsityksiin aikuisten oppimisesta, yhteisöllisyydestä ja yhteiskunnan jäsenyydestä. Jos kansalaisuus tulkitaan aktiiviseksi toiminnaksi, kansalaistaitojen kehittymistä voidaan tukea kansalaiskasvatuksen, vapaan sivistystyön ja aikuiskoulutuksen avulla. Näin määritellyn kansalaisuuden kehittämiseen sisältyy mahdollisuus myös aikuiskasvatuksen kriittisen ja kulttuurisen sivistystehtävän toteuttamiseen. (Ks. Jarvis 2008.)

Aikuiskoulutusta, ammatillista asiantuntijuutta ja työelämän muutoksia koskevaa tutkimustietoa voidaan käyttää aikuiskoulutuksen sisältöjen ja muotojen uudistamisessa. Aikuiskoulutuksen tavoitteena on formaalin aikuiskoulutuksen ja informaalisen oppimisen yhteen nivominen tavalla, joka tukee ihmisten aktiivisuutta ja pyrkii edistämään heidän tietojensa, taitojensa ja kykyjensä monipuolista kehittymistä. Aikuiskoulutuksen yhtenä tavoitteena voisi olla myös ihmisten arkielämässä eli työssä, perheessä ja vapaa-ajan toiminnoissa esiintyvien luonnollisten oppimisprosessien tunnistaminen ja aiemmin hankitun osaamisen hyödyntäminen. Peter Alheit ja Bettina Dausien (2000, 400-422) korostavat, että aikuisille on kertynyt elämänsä varrella monenlaista "piilevää osaamista" 
ja taitoja, joita ei aina pystytä hyödyntämään täysipainoisesti sen vuoksi, ettei niitä tunnisteta. Elämänhistoriallisessa eli biografisessa oppimisessa ihmisiä autetaan heidän elämänhistoriaansa kerrostuneiden, mutta joskus jopa unohdettujen tietojen, taitojen ja kokemusten hyödyntämisessä. Elämänhistoriallista oppimista sekä aikaisemmin hankittuja tietoja ja osaamista hyödyntävässä aikuiskoulutuksessa voitaisiin rakentaa ihmisten tarpeista ja osaamisesta lähteviä koulutusmalleja. Samalla voitaisiin edistää uusien yhteisöllisten rakenteiden ja sidosten muodostumista.

Aikuiskoulutukselta tämä edellyttää työelämänlähtöistä painotusta laajempaa näkemystä aikuiskoulutuksen kannalta tärkeistä asiasisällöistä ja toimintamuodoista. Koulutusta ei ole syytä valjastaa vain työelämän tämänhetkisten tarpeiden palvelijaksi, koska globalisaation aiheuttamassa tilanteessa työelämän osaamistarpeet muuttuvat jatkuvasti. Tähän kysymykseen ovat kiinnittäneet huomiota Tom Schuller ja John Preston (2005, 139153), jotka ovat tutkineet koulutuksen tuottamia valmiuksia - taitoja, verkostoja ja arvoja. Schuller ja Preston ovat erottaneet toisistaan työelämän edellyttämän inhimillisen pääoman, ihmissuhteisiin liittyvän sosiaalisen pääoman sekä yksilöllisen identiteettipääoman. Nämä pääomat toimivat resurssitekijöinä, joiden avulla ihmiset toimivat työssään ja arkielämässään. Työelämän kannalta tärkeiden taitojen ja inhimillisen pääoman kehittäminen ei yksin riitä edistämään ihmisten hyvinvointia ja aktiivista kansalaisuutta, minkä vuoksi aikuiskoulutuksessa on tärkeää ottaa huomioon myös sosiaalisen pääoman ja sosiaalisten verkostojen sekä identiteettipääoman ja yhteisöllisen arvopohjan kehittäminen.

Olen tässä lyhyessä esityksessä tarkastellut aikuiskasvatuksen, sosiologian ja arkielämän välisiä suhteita ja pohtinut, millä tavoin voisimme rakentaa siltoja ihmisten arkielämän tilanteista kumpuavien oppimistapojen ja formaalisten koulutusinstituutioiden välille. Toivottavasti meille voidaan rakentaa sellaisia koulutuksellisia ratkaisuja, jotka kiinnittävät aikaisempaa enemmän huomiota opiskelijoiden oppimisintresseihin ja arkielämästä kumpuaviin osaamistarpeisiin sekä antavat heille mahdollisuuden saada "äänensä” kuuluville. Koulutuksen tavoitteena tulisi Paulo Freiren (2005) ja Stephen Brookfieldin (2005) tapaan olla ihmisten tietoisuuden lisääminen, toimintakyvyn vahvistaminen ja aktiivisen kansalaistoiminnan edistäminen. Myöhäismodernissa yhteiskunnassa, jossa työelämän ohella myös ihmisten arkielämä on käynyt vaikeasti ennakoitavaksi sekä työttömyydestä ja erilaisista muutoksista on tullut pysyvä ilmiö, aikuisten identiteetti ei voi rakentua yksinomaan palkkatyön varaan. Identiteetin rakennusaineksia tulisikin etsiä ihmisten eri elämänalueita ja toimintakompetensseja laajemmin käsittävästä ilmiöstä, kuten aktiivisesta kansalaisuudesta ja sen avaamista mahdollisuuksista ymmärtää uudella tapaa aikuiskoulutuksen ja aikuiskasvatustieteen suhde ihmisten arkielämään.

\section{Lähteet}

\section{Aittola, T. (toim.) (1999). Kasvatussosiologian} teoreetikoita. Helsinki: Gaudeamus.

Alheit, P. (1996). "From labour society to learning society - a provocative proposal". Lifelong Learning in Europe 2 (1), 2-5.

Alheit, P. \& Dausien, B. 2000. "Biograhicity” as a basic resource in lifelong learning. Teoksessa: P. Alheit, J. Beck, E. Kammler, R. Taylor, and H.-S. Olesen (Eds.) Lifelong learning inside and outside schools. Roskilde University press, 400-422.

Antikainen, A. (1998). Kasvatus, elämänkulku ja yhteiskunta. Helsinki: WSOY.

Antikainen A., Houtsonen, J., Kauppila, J. \& Huotelin, H. (1996). Living in a learning society. London: Falmer press.

Antikainen, A. (2005). Aikuiskoulutukseen osallistumisen erojen syyt. Teoksessa: U. Rönnberg (toim.) Aikuiskoulutuksen vuosikirja. Helsinki: Opetusministeriö, 23-32.

Bauman, Z. (2007). Liquid times. Cambridge: Polity.

Beck, U. (2002). A life of one's own in a runaway world. Teoksessa: E. Beck-Gernsheim \& U. Beck. Individualization. London: Sage, 20-29.

Bennett, T. (2005).Culture and everyday life. London: SAGE.

Brookfield, S. (2005). The power of critical theory for adult learning and teaching. New York: Open university press.

Chaney, D. (2002).Cultural change and everyday life. New York: Palgrave.

Felski, R. (2000). The intervention of everyday life. New Formations 39, (Winter), 15-31.

Freire, P. (2005). Sorrettujen pedagogiikka. Tampere: Vastapaino. 
Heller, A. (1984). Everyday life. London: Routledge \& Kegan Paul.

Highmore, B. (2002). Everyday life and cultural theory. London and New York: Routledge.

Jarvis, P. (2008). Democracy, lifelong learning and the learning society. Active citizenship in a Late Modern Age. London: Routledge.

Johnston, R. (2005). A Framework for analysing and developing adult learning for active citizenship. Teoksessa: D. Wildermeersch, V. Stroobants and M. Bron Jr. (Eds.) Active citizenship and multiple identities in Europe. Frankfurt am Main: Peter Lang, 47-63.

Jokinen, E. (2005). Aikuisten arki. Gaudeamus.

Laitinen, M. \& Nurmi, K. (2003). Aktiiviseksi kansalaiseksi kasvaminen suomalaisten elämänkertojen valossa. Aikuiskasvatus 23, (2), 122-132.

Lefebvre, H. (2008). Critique of everyday life IIII. London: Verso.

Mannheim, Karl (1947). On diagnosis of our time - Wartime essays of a sociologist. London: Routledge.

Mills, C.W. (1978). The sociological imagination. Harmondsworth: Penguin books.

Moore, E. (2004).Aikuiskasvatukseen osallistumattomuus on myös rationaalista. Aikuiskas- vatus 24, (3), 206-213.

Noro, A. (2007). Aikalaisdiagnoosi sosiologisen teorian kolmas lajityyppi. Teoksessa J. Gronow, K. Rahkonen \& A. Sinnemäki (toim.) Arto Noro. Small talkia sosiologiasta. Helsinki: Tutkijaliitto, 137-154.

Schuller, T. \& Preston, J. (2005). Skills, values and networks: Evidence on the wider benefits of learning. Teoksessa D. Wildermeersch, V. Stroobants, M. Bron Jr. (Eds.) Active Citizenship and Multiple Identities in Europe. Frankfurt am Main: Peter Lang, 139-153.

Sallila, P. \& Vaherva, T. (toim.) (1998). Arkipäivän oppiminen. Aikuiskasvatuksen 39. vuosikirja. Helsinki: Kansanvalistusseura.

Schutz, A. \& Luckmann, T. (1973). The structures of the lifeworld, Vol. I, Evanston, Ill: Northwestern University Press.

Suoranta, J. \& Salo, P. (2002). Sivistyksellinen aikuiskasvatus. Helsinki: Kansanvalistusseura.

Wittpoth, Jürgen (2001). Erwaschenenbildung und Zeitdiagnose. W. Bertelsmann Verlag: Bielefeld.

Puheenvuoro on professori Tapio Aittolan virkaanastujaispuhe 22. lokakuuta 2008 Jyväskylän yliopistossa.

Tapio Aittolan kuva: Tarja Vänskä-Kauhanen 